\title{
Ciências da Religião nas universidades públicas brasileiras: modelos de implementação e desafios
}

\section{Religious studies in Brazilian public universities: models of implementation and its challenges}

\author{
Frederico Pieper*
}

\begin{abstract}
Resumo: Esse artigo explora a inserção das Ciências da Religião no âmbito das universidades públicas brasileiras. Para tanto, busca responder à pergunta pelo modo como se deu essa inserção e quais as consequências para o perfil dos cursos e os desafios enfrentados. Ao analisar os cursos, seus processos de fundaçáo ocorreram por dois caminhos principais. Os primeiros cursos de licenciatura surgem a partir da forte demanda prática do Ensino Religioso, com ênfases pedagógicas e em universidades estaduais. O outro modelo é constituído pela iniciativa de professores de outras áreas do saber atuantes nas universidades federais e que lutam para implementaçáo do curso. Este conjunto de fatores gera cursos com ênfase no caráter interdisciplinar das Ciências da Religião e o desafio de evidenciar a importância do estudo da religião no ambiente acadêmico.
\end{abstract}

Palavras-chave: Ciências da Religião. Pesquisa. Ensino religioso. Epistemologia.

Abstract: This article explores the introduction of religious studies within Brazilian public universities. It aims to answer the question of how this insertion occurred and the consequences for the courses profile and challenges faced by them. When analyzing the set of courses, we find two main paths to the beginning of religious studies in public universities. The first undergraduate courses arose from the substantial practical demand for religious education in public school, with pedagogical emphases, and in-state universities. The other model is constituted by the initiative of teachers of other areas of knowledge who work in federal universities and who struggle to implement the courses. These factors gave rise to courses with an emphasis on interdisciplinary character and the challenge of highlighting the importance of the study of religion in the academic field.

Keywords: Religious studies. Academic research. Religious education. Epistemology.

Doutor em Ciências da Religião (UMESP). Professor no Departamento de Ciência da Religião (UFJF). ORCID: 0000-0001-5590-2202 - Contato: fredericopieper@gmail.com. 


\section{Introdução}

Escrever sobre a presença das Ciências da Religião ${ }^{1}$ no âmbito das universidades públicas no Brasil não é, ao contrário do que aparenta, tarefa fácil. $\mathrm{O}$ olhar mais quantitativo observa que não há um número expressivo de cursos, inclusive se somamos os de graduação e de pós-graduação. Além do mais, eles somente alcançaram um funcionamento regular mais recentemente na história. Desse modo, se ficamos presos aos números, parece não haver maior complexidade em tratar dessa muito recente presença desse campo disciplinar nas universidades públicas. Mas, a tarefa se torna complexa quando é se observa esse quadro com mais cuidado.

Em primeiro lugar, há uma tensão no que tange à história. Se os cursos de graduação têm funcionamento contínuo apenas nos anos 2000, sua história não se circunscreve a esse período. Na verdade, neste ano de 2019, as Ciências da religião no Brasil completam 50 anos de presença institucional, tendo início em 1969 com criaçáo do Departamento de Ciências das Religiōes da Universidade Federal de Juiz de Fora. Creio que seja correto dizer que a pesquisa e a pós-graduaçáo em Ciência da Religiáo têm quarenta anos. No entanto, se ampliamos o escopo para a graduação, esse campo de estudos se mostra mais antigo.

Considerando esse quadro, esse artigo busca responder à seguinte indagação: como se deu o processo de implementaçáo de cursos de Ciências da Religiáo nas universidades públicas brasileiras? Para responder a essa indagação, não é minha proposta manter-me restrito à mera descrição. $\mathrm{O}$ leitor poderá acessar os dados nas páginas dos cursos e programas ou nas publicações sobre os cursos, às quais faço alusão nas referências bibliográficas. Antes, o que pretendo com esse artigo é, de um lado, captar alguns contornos peculiares dos cursos nas instituiçóes públicas, tentando perceber aspectos compartilhados pelos cursos que se instalaram nessas instituiçóes. Para tanto, utilizarei como fontes informaçôes disponibilizadas nos sites dos cursos, projetos pedagógicos e publicaçôes que tratem do tema. Portanto, o artigo se pauta em informaçôes publicizadas por meios oficiais.

\section{0 anos de história das Ciências da Religiáo na universidade pública}

Quando se observa a história do estabelecimento das Ciências da Religião no Brasil, fica evidente que ela se deu de modo bem próprio. Em geral, as demais áreas do conhecimento tiveram início com a oferta de cursos de graduação, especialmente tendo em vista a formação de profissionais especializados para atender a demandas práticas. Nesses casos, o desenvolvimento mais sistemático de pesquisas, com a oferta de cursos de pós-graduação, ganhou impulso somente após a consolidação da graduação.

1 No contexto das universidades públicas é possível encontrar três designações distintas para os cursos: Ciência da Religião, Ciências da Religião e Ciências das Religiốes. Para fins deste artigo, quando se fizer referências mais gerais, será empregada a terminologia adotada para nomear este campo de estudos na CAPES, a saber, "Ciências da Religiáo". Para se reportar aos cursos, serão empregados os nomes que eles adotam. 
Diferentemente desse padrão, no caso das Ciências da Religião, os primeiros cursos com funcionamento contínuo foram de pós-graduação. Isso se deve ao caráter do objeto de estudo e a aspectos circunstanciais.

De um lado, no Brasil do último quarto do século XX, entendia-se que o estudo da religião era uma especialidade a ser desenvolvida após a formação em uma área do conhecimento. Dessa maneira, o discente teria uma formação inicial em, por exemplo, história, psicologia, sociologia etc. E, no intuito de ter uma especialidade em religião, continuava seus estudos no mestrado em Ciências da Religião. Diante dessa perspectiva, nada mais natural que esses cursos fossem oferecidos no âmbito da pós-graduação. Além do mais, é preciso enfatizar que o reconhecimento de cursos de teologia por parte do Ministério da Educaçáo se deu somente a partir dos anos 2000. Diante desse entrave, alguns programas de pós-graduação viram na opção pelo nome Ciências da Religiáo uma alternativa para estudar religiáo com a chancela do MEC. Em alguns casos, entretanto, isso não implicou alterações epistemológicas mais substanciais nas propostas. Eram cursos com o nome de "Ciências da Religiáo", mas com estrutura de teologia.

No entanto, a consolidaçáo das Ciências da Religiáo com cursos de pós-graduaçáo não significa que a sua história, em especial nas universidades púbicas, tenha tido esse mesmo início. Na verdade, esse processo tem sua gênese há pouco mais de cinquenta anos, em 1968. É deste ano a tentativa de dar início a um departamento dedicado ao estudo da religiáo na Universidade Federal de Juiz de Fora (UFJF). Aproveitando uma proposta de reforma universitária a ser enviada pela universidade para o Conselho Federal de Educaçáo (CFE), um conjunto de professores (em sua grande maioria, padres e ex-padres) encaminha a solicitaçáo de que fosse fundado na universidade um departamento de teologia. Em outros termos, o pedido era que o CFE autorizasse uma universidade pública a possuir um departamento e, consequentemente, um curso de teologia. Em resposta, o documento, assinado por Newton Sucupira em 15 de Março de 1968, afirma o seguinte:

(...) Certamente a Teologia que se tem em vista não é a Teologia da qual falava Aristóteles na Metafísica, nem a Teologia Natural que se costuma chamar Teodicéia desde os tempos de Leibniz e que é uma parte da Metafísica na classificação Wolffiana. É a Teologia Dogmática, ciência do divino como tal que pressupõe formalmente a Teologia, embora utilizando-se de instrumento conceitual próprio. Assim considerada, como bem acentua J. B. Metz, discípulo de um dos mais eminentes teólogos modernos, Karl Rohner [sic], a Teologia distinguindo-se da pura Filosofia da Religião, tem na fé a base e a finalidade de seu Leges (Cf. Lexikon für Theologie und Kircheh [sic], Bd.X Verlag Herder Feiburg - 1965). Tradicionalmente, os estudos teológicos, nas universidades que possuem Faculdade de Teologia, são considerados como saber de cúpula, destinos à formação profissional do clero, pressupondo o que hoje chamamos de formação básica.

Por êstes [sic] motivos, sugerimos que, em vez de Instituto de Teologia, esja [sic] criado no Insttituto [sic] de Ciências Humanas um Departamento de Ciências da Religião, neste Departamento o fenômeno religioso pode ser estudado em seus vários aspectos, podendo ser ministrados cursos sôbre [sic] e de Teologia (Parecer No 190/68, aprovado em 15 de Março de 1968, Processo 733/67). 
Este documento, a meu ver, se configura como a certidão de nascimento institucional das Ciências da Religião no Brasil. Dentre outras coisas, ele indica que o nome Ciências da Religião não nasce de uma reivindicação das bases, mas é uma proposta de nomenclatura que tem origem no órgão responsável do governo federal. A depender da solicitação feita, ocorreria um caso inédito no Brasil: um curso de teologia em uma universidade pública ${ }^{2}$. No entanto, ao entender que a teologia dogmática teria por finalidade a formação do clero, Sucupira veta essa intenção. Em seu lugar, propóe outra designação e abordagem capaz de contemplar de maneira mais ampla o estudo da religião em seus diversos aspectos, incluindo o estudo sobre e de teologia.

A recomendação, com alteração da nomenclatura para Ciências das Religióes, foi acatada e, dessa maneira, em 1969, surgia numa universidade pública o primeiro departamento dessa natureza na América do Sul. No entanto, o processo para implementação de um curso foi bem mais penoso e prolongado. A partir da fundação do Departamento de Ciências das Religióes, os professores planejaram um curso de graduação. Em 1974, é enviada ao CFE uma consulta tendo em vista o estabelecimento de uma licenciatura, inclusive com proposta de um currículo mínimo, cujo objetivo principal era a formação de professores de Ensino Religioso (UFJF, Aviso 142 de 07/02/1974) ${ }^{3}$. O parecer, pautado em argumentos bastante frágeis, nega a possibilidade de oferta do curso. Basicamente, o relator confunde estudo sobre religiáo com propagação de fé religiosa. Partindo dessa falsa premissa, o CFE entende que não deveria interferir em questóes religiosas e que caberia aos ministros religiosos indicar os professores de ensino religioso. Ademais, pergunta como seria possível a formação de um professor a-religioso e totalmente imparcial na abordagem do fenômeno religioso (Parecer No 2244/74, Processo 6.930/74 CFE, p. 331).

Uma vez que o parecer não vetava a oferta do bacharelado, foram feitos dois vestibulares em Ciências das Religióes na UFJF, sendo admitidas duas turmas de dez discentes cada uma. No entanto, em 1977, por meio de articulaçóes entre setores positivistas da universidade e o clero local, o curso é proibido de abrir novos vestibulares, funcionando a partir de então como curso livre. $\mathrm{O}$ argumento era de que não havia diretrizes curriculares para essas graduações, o que, segundo a legislação da época, impedia seu funcionamento com a chancela das instâncias competentes. Na prática, essa decisão implicava o encerramento do curso. Durante toda a década de 1980, os professores do departamento, que a essa altura ofereciam disciplinas para outros

2 Essa possibilidade havia sido colocada por Darcy Ribeiro ao planejar a Universidade de Brasília. Segundo um relato feito em 1995, "Procurei em São Paulo o Geral, no Brasil, da Ordem, que era Frei Mateus Rocha, e lhe expus o meu problema. Argumentei que o Brasil tinha oito universidades católicas, quatro delas pontifícias, que formavam milhares de farmacêuticos e dentistas, mas não formavam nenhum teólogo. Propus entregar aos dominicanos a criaçáo de um Instituto de Teologia Católica dentro da Universidade de Brasília. Seria um ato revolucionário, porque a teologia, expulsa das universidades públicas desde a Revoluçáo Francesa, a elas voltariam, justamente na mais moderna universidade que se estava criando naqueles anos. Houve reaçóes adversas à minha iniciativa, inclusive a de um eminente cientista, que me acusava de trair a tradição laicista da educação" (Ribeiro, 1995).

3 Nesse momento, de maneira independente, há iniciativas em Santa Catarina para o início de uma licenciatura em Educaçáo Religiosa. Essa proposta, reiterada sucessivas vezes, foi recusada pelo Conselho Federal de Educação (CFE) com base em razóes legais. Sobre isso, cf. Oliveira, 2003. 
cursos, elaboraram projetos pedagógicos de cursos de graduaçáo e especializaçáa. No entanto, somente conseguem implementar a especialização na década de 1990 e, logo em seguida, o mestrado. A graduação demandaria ainda mais tempo, tendo início somente em $2012^{4}$.

Esse breve relato histórico é evidência daquilo que era anunciado na Introdução. Abordar as Ciências da Religião no âmbito das instituições públicas de ensino superior no Brasil revela-se um pouco mais complexo do que parece. Os primeiros passos para a institucionalizaçáo desse campo de estudos no Brasil foram dados no âmbito de uma universidade pública. Isso não foi feito sem resistências e interferências de várias instâncias. Essas forças contrárias fizeram com que a oferta continuada de um curso fosse adiada por algum tempo.

\section{Ciências da Religiáo nas universidades públicas: dois modelos e seus desafios}

No sistema de ensino universitário brasileiro, existem dois tipos de universidades que são consideradas públicas e que possuem cursos de Ciências da Religião: estaduais e federais. Considerando essa distinção, para termos panorama mais bem definido do quê estamos falando ao nos referir a universidades públicas, segue abaixo um quadro das instituiçôes com cursos de graduação e pós-graduação em funcionamento, ordenados segundo o ano de fundação do curso.

\section{Graduaçáo}

\begin{tabular}{lcc} 
Instituiçáo & Ano de início & Regiáo \\
\hline Universidade Federal de Juiz de Fora (UFJF) & $\begin{array}{c}1976-1977 \\
2012\end{array}$ & Sudeste \\
\hline Universidade do Estado do Pará (UEPA) & 1999 & Norte \\
\hline Universidade do Estado do Rio Grande do Norte (UERN) & 2001 & Nordeste \\
\hline Universidade Estadual de Montes Claros (UNIMONTES) & 2007 & Sudeste \\
\hline Universidade Federal da Paraíba (UFPB) & 2011 & Nordeste \\
\hline Universidade Federal do Sergipe (UFS) & 2011 & Nordeste \\
\hline Universidade Estadual do Amazonas (UEA) & 2015 & Norte \\
\hline Universidade Federal Santa Maria (UFSM-UAB) & 2016 & Sul
\end{tabular}

4 Abordagem mais detalhada desse período pode ser encontrada no meu artigo: Pieper, 2018, pp. 232291. Neste mesmo número, recomendo também as entrevistas conduzidas por Matheus Oliva da Costa com o ex-professor do curso Wolfgang Gruen e com os ex-alunos Faustino Teixeira e Paulo Agostinho (Costa, 2018a, $2018 b, 2018 c$ ). Há também um depoimento de Faustino Teixeira, um dos alunos desse curso na década de 1970 e que retorna como professor na década de 1990. Teixeira, 2012, pp.537-550. 


\section{Pós-graduaçáo}

\begin{tabular}{lcc} 
Instituiçáa & Ano de início & Regiáo \\
\hline Universidade Federal de Juiz de Fora (UFJF) & 1993 & Sudeste \\
\hline Universidade Federal da Paraíba (UFPB) & 2007 & Nordeste \\
\hline Universidade do Estado do Pará (UEPA) & 2008 & Norte \\
\hline Universidade Federal do Sergipe (UFS) & 2014 & Nordeste
\end{tabular}

O quadro que se refere aos cursos de graduação nos mostra que a criação dos primeiros cursos com oferta contínua ocorreu em universidades estaduais. No início dos anos 2000, a UEPA e a UERN oferecem as primeiras licenciaturas. Na outra parte da coluna, especialmente nos anos 2010, constata-se o surgimento de cursos de graduaçáo nas universidades federais. Há uma razáo para esse ordenamento cronológico. Como será observado, muitos cursos de graduação, especialmente pensando nas licenciaturas, surgem a partir de demandas para formação de professores para o Ensino Religioso. Uma vez que ele é componente curricular da educação básica, esses estados promoveram a formação específica para os professores, especialmente a partir da Lei № 9.394/96 (complementada pela Lei No 9.475/97) da Lei de Diretrizes e Bases da Educação, que regula o Ensino Religioso. Valendo-se desse aparato legal, foi possível pressionar as instâncias administrativas das universidades para criaçáo desses cursos.

Já nas universidades federais, o surgimento de cursos nos anos 2010 pode ser explicado a partir do projeto, encampado pelo governo de Luís Inácio Lula da Silva, de expansão e reestruturação das universidades federais, o REUNI. O projeto, que praticamente dobrou o número de alunos em universidades públicas, criou novas universidades, novos campi, e possibilitou a expansão das já existentes. O investimento feito e a contratação de novos professores fomentou a implementação dos cursos de graduação, inclusive em instituições onde antes havia apenas cursos de pós-graduação em Ciências da Religião, como foi o caso da UFJF e UFPB. Nesse caso, os cursos de pós-graduação também foram beneficiados e saíram fortalecidos. Portanto, a meu ver, o surgimento desses cursos encontra sua condição de possibilidade nessa política pública adotada pelo governo federal. Sem dúvida, esse fator deve ser conjugado com outros. No entanto, o REUNI criou as condições objetivas para a implementação e fortalecimento dos cursos dessas instituiçóes, o que pode nos auxiliar a entender $\mathrm{o}$ aspecto cronológico da tabela. Analisemos os dois modelos mais detidamente.

\section{Do Ensino Religioso às Ciências da Religiáo}

Esse primeiro modelo se aplica ao surgimento de cursos de licenciatura a partir do início dos anos 2000, que ocorre, sobretudo, em universidades estaduais. Eles são fomentados a partir de atuaçōes de grupos ecumênicos e eclesiásticos que, devido à ausência de uma presença mais efetiva do Estado, se ocupavam do Ensino Religioso. Isso se dava, principalmente, na formaçáo de professores aptos a ministrar este componente curricular na educação básica. Nesse sentido, esses cursos tendem a ter ênfase prática, 
e têm como desafio superar a perspectiva confessional tanto do componente curricular Ensino Religioso como das propostas dos cursos.

Para melhor entendimento desse modelo, é preciso atentar para o fato de que, nas décadas de 1970 e de 1980, era recorrente no contexto brasileiro a formação de grupos ecumênicos que assumiram para si a responsabilidade sobre o Ensino Religioso. Essa atuação dizia respeito não somente à indicação de professores considerados competentes para assumirem essas aulas na educação básica, mas também na produção de material didático e no oferecimento de cursos de formação para os professores (cf. Junqueira, 2014).

A fim de não se incorrer em anacronismos nas análises, é importante compreender essas propostas de Ensino Religioso dentro dos limites das condiçóes históricas daquele momento. Esse modelo ecumênico, por exemplo, por mais que se fie no entendimento de que o Ensino Religioso deve se ocupar com valores, representa um avanço em relação à proposta catequética, de pura reprodução dos ensinos de apenas uma denominação religiosa, em geral a dominante em termos numéricos. Não obstante essa abertura, tal proposta entendia como função do Ensino Religioso o desenvolvimento de certa dimensão religiosa dos educandos, náo a enfatizando suficientemente como objeto de estudo, sobre o qual é possível estabelecer conhecimentos. Além dos mais, esse ecumenismo era, em quase todos os casos, restrito a denominaçóes de tradição cristá.

Sob essas condiçóes, por exemplo, tem início a licenciatura da UEPA. Antes da efetiva implementação do curso na universidade, há iniciativas de trabalho conjunto entre a arquidiocese de Belém e a Secretaria de Estado da Educação. Essa pareceria se estabelece pelo menos desde os anos de 1970. A proposta era de que fossem oferecidos aos professores da educação básica cursos de formação, bem como material didático, custeado pela arquidiocese e fornecido gratuitamente aos professores (Santos, Costa, Souza, 2017, p. 62). Com o passar dos anos, os concluintes passaram a ter seu diploma chancelado pelo Conselho Superior de Ensino e Pesquisa da Universidade Federal do Pará (Conceição, 2012, p. 306). Para resumir o percurso, a institucionalização do curso na universidade pública aconteceu quando muitos dos professores que atuaram nos cursos de formação fomentados pela arquidiocese se tornaram efetivos na UEPA. Nesse momento, e diante da demanda legal por professores qualificados para o Ensino Religioso, surge a proposta de uma licenciatura em Ciências da Religião no âmbito desta instituição de ensino superior.

Caso similar ocorre com o curso da UERN. Com algumas diferenças mais pontuais, o processo de implementação segue estrutura muito próxima da do caso anterior. A partir de 1977, o Instituto de Teologia Pastoral da Arquidiocese de Natal (ITEPAN) funda a Escola Superior de Educação Religiosa (ESER), cujo objetivo era formar professores de Ensino Religioso para educação básica no Rio Grande do Norte. Pouco mais de dez anos após sua fundação, ela é autorizada a funcionar pela Secretaria de Educação do Estado, contando também com autorização do Conselho de Educação. Mesmo não tendo o aval federal, no âmbito estadual seu estatuto era equivalente ao de uma graduação, inclusive para finalidades salariais dos professores (UERN, 2006, p. 17). Nos anos 2000, num momento de expansão da universidade estadual e diante da necessidade de professores de Ensino Religioso para a educação básica, é criada, em 
2001, a licenciatura em Ciências da Religiáo (Benevides et alii, 2017, pp. 79-80). Esse curso funcionou em parceria com a ITEPAN até 2011, quando também houve mudança nas instalaçôes onde o curso era oferecido (UERN, 2014, p. 26). Cabe ressaltar que muitos dos professores possuíam formação em alguma área do conhecimento (Letras, História etc.) e em Educação Religiosa pela ESER.

Para não me tornar repetitivo, não pretendo retomar o desenvolvimento histórico de cada curso que se insere nesse modelo. Mas, há paralelos nos casos da Universidade Estadual do Amazonas (Silva, Palheta, 2017, p. 34) e da Universidade de Montes Claros (Borges, Horácio, 2017, p.145). Em todas essas situações, deparamo-nos com cursos de graduação, especialmente de licenciatura, que se instalam na universidade como resultado de inciativas de associações religiosas. Com isso, fica claro como a aplicação das Ciências da Religiáo no Ensino Religioso é importante propulsor e mecanismo de expansão da área.

Para criar as condiçóes institucionais, a legislação se mostra como instrumento fundamental para a pressão nas instâncias administrativas das universidades. Em todos os relatos da história desses cursos ao qual tive acesso, esse fator é mencionado. A legislação mais específica e que pode servir como instrumento de justificativa para o curso é relativamente recente. Trata-se da Lei No 9394/96 complementada pela Lei No 9475/97. Ou seja: do ano 1996/97. Esse também é um elemento que nos auxilia a perceber a razão pela qual os primeiros cursos de graduação remetem para início dos anos 2000 .

Chama a atenção também que, na história pregressa de muitos desses cursos em universidades públicas, as atuaçôes bastante vigorosas das instituições religiosas foram determinantes. A presença inicial de cursos de graduação em Ciências da Religiáo nas universidades estaduais ocorre como derivação de inciativas patrocinadas por instituiçôes religiosas, principalmente católicas. Essa configuração dos cursos gera algumas reflexôes importantes para se pensar a presença das Ciências da Religião nas instituiçôes públicas de ensino superior. Dada essa conjuntura institucional, levanta-se um importante desafio: como superar o caráter confessional, tanto do componente curricular Ensino Religioso quanto da formação do professor?

A julgar pelos documentos, os cursos percebem essa questão muito cedo. Isso aparece na ênfase recorrente que se dá ao tema da pluralidade ou da interculturalidade. $\mathrm{O}$ destaque a essas temas se mostra como o caminho para superar um modelo confessional ou proselitista de Ensino Religioso. Além do que, esses eram critérios fundamentais para se atender às exigências da legislação vigente. Mas, a passagem de uma compreensão do Ensino Religioso como portador de uma função religiosa para lhe dar uma conotação social de formação do cidadão demandou mais tempo. Ela ocorre quando se toma assume efetivamente as Ciências da Religiáo como área de referência do Ensino Religioso.

O desenvolvimento da discussão em torno do Ensino Religioso tem avançando, já há algum tempo, no sentido de mostrar que esse componente curricular deve abordar o tema da religião propriamente dito. Isso deveria ser o óbvio. Mas não era a prática que se adotava até muito recentemente e, em muitos lugares, não é ainda o que se faz. Em alguns casos, ele era tido como espaço para promoção de valores morais religiosos estabelecidos, reforçando os padróes de comportamento tradicionalmente aceitos. 
Entretanto, a aproximação com as Ciências da Religiáo, com sua ênfase no estudo comparado de tradições religiosas a partir de temas específicos, o objeto religião tem sido trazido para o centro da cena ${ }^{5}$. A questão que disso decorre é pelo modo adequado de abordar esse tema.

De certa maneira, é possível acompanhar esse desenvolvimento no modo como os cursos que estamos analisando estruturam seu conjunto de disciplinas e demais itens do projeto pedagógico. Vejamos algumas evidências a partir de extratos retirados dos projetos pedagógicos dos cursos. O projeto pedagógico da Universidade do Estado do Amazonas (UEA), ao tratar do perfil do egresso, diz que ele dever ser apto a "Reconhecer, respeitar e valorizar a diversidade e a complexidade das manifestaçóes e experiências religiosas no contexto escolar e social" (Sales, Palheta, 2017, p. 39). Afirmações similares a essa aparecem em praticamente todos os outros projetos pedagógicos de cursos de graduação das universidades públicas.

Esses objetivos repercutem na organização curricular. Em sua maioria, os cursos possuem um conjunto de disciplinas de formação básica que remetem para áreas das ciências humanas (filosofia, sociologia, antropologia, etc), especialmente no que toca a suas abordagens da religião. Num eixo mais específico, há o tratamento das tradiçôes religiosas. Nos casos que estamos analisando, as disciplinas são nomeadas como "Teologia das Tradiçôes Religiosas I e II" ou "História das Narrativas Sagradas I". Ao se verificar as ementas, em muitos casos, elas não indicam que tradiçôes religiosas especificamente devem ser abordadas em cada disciplina. Em outros casos, principalmente nos projetos mais recentes, nota-se um direcionamento maior nas ementas, mas que também não chega a especificar vertentes religiosas, utilizando-se de nomes como "Tradiçôes religiosas orientais". Enfim, apesar de se destacar a pluralidade, é de se perguntar se elas são captadas em suas especificidades próprias ou são analisadas de modo mais panorâmico. Em parte, isso se deve ao caráter comparativo, à demanda prática de uso dessas informaçôes na educaçáo básica e à carência de especialistas em certas tradiçóes religiosas, notadamente aquelas menos visibilizadas no contexto nacional.

Esses cursos se iniciam com um corpo docente com as mais variadas formaçóes, com destaque para Educação, mas raras vezes conta com professores com alguma titulação em Ciências da Religião. Esse fator tem sua repercussão nos projetos dos cursos, especialmente em questōes muito centrais. Se há a percepção muito lúcida de que a pluralidade e a diversidade devem ser contempladas, a pergunta seguinte se articula na direçáo do que e como deve ser entáo ensinado sobre religiáo para que esses

5 Essa perspectiva aparece tanto nos documentos normativos como na literatura sobre o tema. Segundo a Base Nacional Comum Curricular: "Cabe ao Ensino Religioso tratar os conhecimentos religiosos a partir de pressupostos éticos e científicos, sem privilégio de nenhuma crença ou convicção. Isso implica abordar esses conhecimentos com base nas diversas culturas e tradiçóes religiosas, sem desconsiderar a existência de filosofias seculares de vida" (BRASIL. Ministério da educação. Base Nacional Comum Curricular para a educação básica. Disponível em: http://basenacionalcomum.mec.gov.br/wp-content/uploads/2018/02/bncc-20dez-site.pdf, p. 434). Para Sérgio Junqueira, "A compreensão da religião como objeto do ensino religioso, compreendida como o estudo das diferentes manifestações que interferem na formação da sociedade e que são estudadas pela Ciência da Religião no espaço acadêmico, subsidia a transposição didática para o cotidiano da sala de aula que favorecerá aos estudantes da educação básica a compreensão da cultura das diferentes comunidades que formam o país. Portanto, a Ciência da Religiáo é a área que constituirá os fundamentos para o ensino religioso orientar seu conteúdo e sua forma no processo da educação" (Junqueira, 2013, p. 609). 
elementos sejam adequadamente abordados. Para tanto, muitos desses cursos acabam se organizando a partir dos eixos que tratam de tradiçóes religiosas, textos sagrados, teologia das religiôes, ritos e ética. Nesse sentido, cabe destacar o importante papel que as Diretrizes Curriculares elaboradas pelo Fórum Nacional Permanente do Ensino Religioso (FONAPER) tiveram para a estruturação desses cursos (FONAPER, 1997). Mesmo que seu foco seja a educação básica, essas diretrizes também tiveram impacto na formulação desses cursos de licenciatura das universidades públicas.

Ao lado da ênfase na pluralidade, outro importante movimento que se nota é o da superaçáo do modelo interconfessional em direçáo a uma mais decisiva aproximação do aparato teórico das Ciências da Religiáo. Em outros termos, os cursos não apenas adotam esse nome, mas buscam abordagens mais condizentes com ele. Do ponto de vista mais geral, a consolidação dessa concepçáo dá-se a partir de 2006, no $9^{\circ}$ Seminário Nacional de Capacitação Profissional para o Ensino Religioso, realizado pelo FONAPER em parceria com a PUC-SP (SOARES, 2009, p. 3). Defende-se que as Ciências da Religiáo, pautadas em referenciais acadêmicos e científicos para estudo sobre a religiáo, pode fornecer instrumentos adequados e condizentes com a laicidade do Estado para o conhecimento sobre religiáo, pois se evita tanto abordagens reducionistas como posturas apologéticas e proselitistas. A religião, nessa perspectiva, deixa de ser alvo de pregação ou de crítica apaixonada, para ser estudada como dimensão constituinte da cultura.

Assim, afirmar que o objeto de estudo deve ser a religiáo em sua pluralidade não significa justificar esse componente curricular com base em sua função religiosa. Enfatiza-se o estudo de temas religiosos e das tradiçóes religiosas. Mas, o argumento que justifica o oferecimento do Ensino Religioso não é religioso, mas social. Em termos práticos, isso significa que legitimar o estudo da religiáo nas escolas tendo em vista o desenvolvimento de uma espiritualidade ou dimensão religiosa do educando é visto com enormes (e a meu ver, justificadas) desconfianças. Essa dimensão tem seu lugar nos espaços religiosos. Por outro lado, alegaçôes com contornos políticos e sociais justificam sua presença na educaçáo básica. Os argumentos de que o ensino sobre a religiáo nas escolas tem a finalidade de estimular a convivência com a diferença nos espaços democráticos ou como componente fundamental da formaçáo cidadã o torna justificável numa estrutura laica (Rodrigues, 2013). Enfim, ainda que o objeto seja a religiáo (ou o fenômeno religioso), a justificativa para seu ensino não é propriamente religiosa, mas política e social: formar cidadáos habilitados para o diálogo e atuação numa sociedade democrática. Gradativamente, à medida que se assume o significado de que as Ciências da Religião são área de referência, essa percepção parece ganhar mais respaldo, ainda que não seja unânime. Esse assumir de modo efetivo traz benefícios para ambos os lados. A pesquisa e as Ciências da Religião passam a dar alguma atenção, ainda muito inicial, à Ciência da Religiáo Aplicada. Ao mesmo tempo em que o Ensino Religioso tem condiçôes de reconhecer suas especificidades na sua abordagem da religião a partir desse diálogo.

Essa transição pode ser notada quando se compara dois trechos do Projeto Pedagógico do curso de Ciências da Religiáo da UERN. No primeiro projeto, em 2001, ao justificar o curso, por meio do item "Caracterização da demanda social" aponta-se a necessidade de profissionais habilitados e se diz: 
Frente a estes dados está mais do que comprovado a necessidade urgente da criação do curso de Ciências da Religião, curso esse de caráter inter-religioso e ecumênico, para formar profissionais competentes para ensinar com profundidade, em termos morais, éticos e religiosos com o intuito de qualificar cidadãos conscientes e críticos para enfrentar a realidade contraditória do mundo atual (UERN, 2001, p. 21).

Da citação acima, chamo a atenção para a preocupação em se destacar que o curso tem caráter inter-religioso e ecumênico. De certa maneira, afirmaçóes dessa natureza refletem resquícios da concepção anterior que animava o curso. Isso, por sua vez, se espelha nas competências que se espera dos profissionais. No entanto, passados sete anos, no mesmo item, o parágrafo assume uma nova formulação. Nessa nova redação, ao invés de se dar acento ao caráter ecumênico, destaca-se a proximidade com as Ciências da Religião. Isso, por sua vez, leva ao destaque do fenômeno religioso como fenômeno humano. Segundo as palavras do projeto,

\begin{abstract}
Assim, cabe a esse professor também capacitar-se para assumir a nova identidade da área, a qual passa a constituir-se como componente que concorre para a formação do cidadão. Com isso, abandona-se o velho modelo confessional e catequético para assumir um novo que tem como prerrogativas o respeito à diversidade religiosa e a formação crítico-reflexiva do aluno. Não é, portanto, doutrinar ou fazer proselitismo religioso, mas antes oferecer aos estudantes a oportunidade de ver o fenômeno religioso enquanto manifestação humana e social presente na história das diferentes culturas. (UERN, 2008, p. 9)
\end{abstract}

Esse trajeto deixa também suas marcas na matriz curricular. É possível notar que, mesmo quando ocorrem pequenas alteraçóes, elas apontam na direção de se ter observar com mais cuidado a realidade local e a gradativa inserção de disciplinas teórico-metodológicas das Ciências da Religião, como, por exemplo, "Introdução às Ciências da Religiáo" ou suas equivalentes.

Em poucas palavras, um primeiro modelo de inserção das Ciências da Religião em universidades públicas se dá por meio da promoção de cursos de licenciatura, com forte ênfase na sua importância para a educação básica. Em geral, esses cursos são decorrentes de iniciativas eclesiásticas e se instalam em universidades estaduais. Para esse modelo, o grande desafio é superação da concepção confessional da abordagem da religiáo, o que se dá por meio do acento na pluralidade e diversidade, bem como com a gradativa e cada vez mais decidida, ainda que não sem conflitos, apropriação das contribuições da Ciência da Religião.

\title{
Das ciências humanas para as Ciências da Religiáo
}

Ao lado dessa primeira tendência, há outro padrão de inserção das Ciências da Religião nas universidades públicas. Ele se caracteriza pela proposição de cursos feita por professores já atuantes em cursos nessas universidades (principalmente, de ciências humanas) e que percebem a religião como tema incontornável de nossa época e, portanto, lutam pela inclusão e reconhecimento da importância de abordá-la no espaço acadêmico.

Algo a se considerar quando tratamos de universidades públicas são as singularidades institucionais que se enfrentam ao se propor um novo curso, especialmente de Ciências 
da Religião. Antes de tudo, há demandas de ordem burocrática. A apresentação de novo curso, especialmente um que não é tăo conhecido no contexto nacional, implica em aprovaçáo em vários colegiados, realocação de verbas, de vagas de professores e de funcionários. Portanto, uma primeira tarefa se impóe num campo bastante prático e de luta político-institucional de justificar recursos para uma área pouco conhecida. Por isso mesmo, como já destacado, uma condição de possibilidade de inserção das Ciências da Religião nas universidades públicas, especialmente as federais, são as políticas governamentais em relação ao ensino superior. Nesse sentido, foi fundamental o programa de Reestruturaçáo das Universidades (REUNI).

No entanto, essas condiçóes seriam inócuas se não fossem conjugadas com o trabalho de professores de outros campos de estudo (filosofia, história, ciências sociais etc.) que atuavam em suas respectivas áreas no âmbito universitário, mas reconheceram a importância do estudo da religiáo. Em termos práticos, se não fosse esse empenho que tem de enfrentar barreiras políticas, burocráticas e epistemológicas no interior das universidades - não teríamos cursos de Ciências da Religião nas universidades federais. Essa afirmação é válida para as primeiras inciativas na UFJF na década de 1970, como também para as mais recentes.

Em segundo lugar, não se pode ignorar o antagonismo no meio acadêmico brasileiro em se reconhecer a legitimidade do estudo sobre religiáo e, portanto, a pertinência de um curso dedicado exclusivamente a esse objeto. Essa oposição e/ou desconfiança se radica em incompreensôes básicas. A mais recorrente é a não diferenciação entre propagar religião e estudar sobre religião. No final do século XIX, quando Friedrich Max Müller propunha uma Ciência da Religião, uma de suas intençóes era justamente demarcar essas fronteiras ${ }^{6}$. O objetivo dessa emergente disciplina não era a propagação de uma visão religiosa de mundo ou de determinada tradiçáo religiosa, mas fazer da religiáo um fenômeno a ser estudado academicamente. No entanto, ainda impera no senso comum e em setores do meio acadêmico essa confusão, como se abordar religiáo nessas instituiçóes representasse ameaça à laicidade da universidade pública. Há uma compreensão bastante estreita, e com nefastas consequências, de que laicidade significaria abstenção da discussão do tema religiáo. Não se percebe, entretanto, que a ausência de debate sobre religiáo náo elimina o tema, mas aumenta sobremaneira o risco de deixar intocadas certas perspectivas intolerantes, seja por conceber uma tradiçáo religiosa como absoluta e/ou por visões distorcidas sobre outras manifestações religiosas. Portanto, o debate bem conduzido do tema religioso náo é ameaça à laicidade, mas o contrário: ele promove reconhecimento mútuo das diferenças e posturas tolerantes. É um serviço à democracia.

Um exemplo bastante significativo nessa direção é encontrado na história do Departamento de Ciência da Religião da UFJF. Na década de 1970, houve dois vestibulares para graduação. No entanto, em 1977, nota-se mobilização do arcebispo da cidade, bem como de setores positivistas e conservadores da universidade, especialmente ligados à faculdade de Direito, no sentido de propor o fechamento do curso. Esses casos

6 Textualmente, afirma: "uma Ciência da Religião, baseada na comparação verdadeiramente científica e imparcial de todas [...] religióes da humanidade, é agora uma questão de tempo" (Müller, 1893, p.26) 
são sintomáticos para se notar como, nessas situaçóes, alianças a princípio inimagináveis acabam ocorrendo: setores eclesiásticos e positivistas. O debate vai para os jornais da cidade. Numa das várias manifestações em torno da questão, Hilton Japiassu aponta justamente os obstáculos colocados pela herança positivista. Segundo ele:

\begin{abstract}
A Universidade de Juiz de Fora estava de parabéns. Porque havia ousado superar o velho ranço positivista, com seus preconceitos obscurantistas, e instaurado em seu seio o curso de Ciências das Religióes. Fato pioneiro no Brasil. E único. Digno da grande envergadura de inteligência de quem lutou por tal implantação. Apesar de ser um curso que, na mentalidade dos que não pensam, dos burocratas do saber, dos que são comandados por uma filosofia mercantilista e pragmatista, dos que reduzem o saber a uma ideologia pecuniária do "status" que possa conferir a formação universitária. (...) Seria lamentável que a inteligência dos homens de Juiz de Fora viesse, de vez, a esclerosar-se; que sua visão se tornasse míope; que sua mentalidade fosse táo provinciana e pequena para ter medo de um curso que só vem ampliar os horizontes mentais... (Japiassu, 1977, p. 2).
\end{abstract}

Nessa defesa da legitimidade do curso, Japiassu ataca a visão estreita em relação ao tema sustentada por burocratas, que não pensam além do limitado horizonte da formação de mão-de-obra para o mercado e de aplicação prática. Cabe ressaltar que positivista é empregado não somente no sentido de desconfiança em relação à pertinência de se estudar esse estágio "ultrapassado" da humanidade, mas também nessa visão utilitarista, que exclui ou considera de menor valor o cultivo de valores humanistas ${ }^{7}$.

Esse desafio, por ser fruto de um mal entendido sobre o que se propóe a pesquisa em Ciências da Religião, foi enfrentado pelos cursos por meio do diálogo com os pares, mas principalmente ao evidenciarem a atualidade, interesse e rigor no estudo da religião. Testemunho sobre essa mudança de percepção é encontrada no processo de implementação do curso de Ciências da Religião da Universidade Federal de Sergipe (UFS):

\begin{abstract}
Inicialmente alguns colegas de outros departamentos enxergavam "Ciências da Religião" como um "corpo estranho" no mundo acadêmico. Havia inclusive desconfianças de que a Universidade estaria se deixando influenciar por ingerências eclesiásticas e desviando-se do princípio da laicidade. Porém, no decorrer desses primeiros anos, até mesmo docentes de outros departamentos que não viam com bons olhos um curso dessa natureza, aos poucos têm percebido que a cientificidade de nossa área implica (e exige!), além de rigor acadêmico, um suficiente afastamento de instituiçóes religiosas e uma postura de "neutralidade" em relação ao objeto de estudo (Ramalho, Calvani, 2017, p. 105).
\end{abstract}

Outro exemplo é encontrado no curso da Universidade Federal da Paraíba (UFPB). Os primeiros movimentos que culminam com o início do mestrado em 2006 remetem para 1994. Na pós-graduação em Sociologia foi ofertada a disciplina: "Religião e Sociedade". A procura e o interesse suscitados por ela levaram à criaçáo de um grupo de pesquisa, RELIGARE. Nesse caso, repete-se algo que já pontuamos como característico do surgimento dos cursos nas universidades federais: o grupo de pesquisa nasce

7 Há relato parecido sobre processo de implementação do curso na UEPA. Devido à falta de discussóes epistemológicas do estudo da religiáo, ainda pensando como função dos centros de formação religiosa, questionou-se o lugar desse tipo de estudo no âmbito da academia (Santos, Costa, Souza, 2017, p. 65). 
com caráter interdisciplinar, reunindo professores e discentes de várias áreas do saber com interesse no estudo da religião. A partir desse grupo de pesquisa formou-se um curso de extensão. A isso, soma-se a demanda da secretaria de educação do estado da Paraíba para que se propiciasse capacitação para os professores de Ensino Religioso. Dessa maneira, em 2005, implementa-se a especialização, que representou passo crucial para a organização do mestrado em Ciências das Religiōes dois anos depois (Miele, Possebon, 2012, pp. 421-422).

Esse exemplo ilustra como esses cursos vão se articulando no interior das instituiçôes. Esse processo de convencimento da pertinência da proposta não ocorre de um momento para o outro. No caso da UFPB, foram 13 anos desde o oferecimento de uma disciplina sobre religião até a abertura da primeira turma do mestrado. Nesses casos, a resistência aos cursos e ao estudo da religiáo vai cedendo à medida que o meio acadêmico reconhece a relevância social que a religião adquiriu nos últimos tempos, o que se reflete no interesse que desperta em discentes e pesquisadores. Os relatos destacam a grande procura que disciplinas, cursos e grupos de pesquisa tiveram. Ao lado disso, percebem-se os limites de certas áreas do saber ou abordagens em lidar com ele. A sua complexidade exige pesquisadores com especialização e domínio dos léxicos das tradiçóes religiosas, de suas teologias e práticas, bem como de teorias da religião.

A inserção das Ciências da Religião no ambiente das universidades públicas a partir da iniciativa de professores de áreas de estudo já consolidadas no ambiente universitário traz como consequência a ênfase no caráter interdisciplinar. Em praticamente todas as descriçôes do curso, o termo aparece com grande destaque. De certa forma, ele acaba sendo bastante conveniente. Uma vez que grande parte dos professores náo possui titulação na área, a interdisciplinaridade, tida como característica inerente das Ciências da Religião, acaba vindo a calhar. Essa configuração, certamente, favorece bastante o estudo de questóes mais específicas. O filósofo continua ensinado e pesquisando em filosofia da religião, o antropólogo desenvolve suas pesquisas de campo sobre faces contemporâneas do fenômeno religioso e o historiador continua empreendendo suas análises de documentos históricos de temas relativos à religião. Essa divisão favorece expressivo avanço nas pesquisas mais específicas.

No entanto, penso que o alerta que Joachim Wach emitia em 1924 continua válido. Segundo ele, "As mesmas condições que se mostram muito frutíferas para o trabalho prático tem sido menos favoráveis à reflexão teórica. Ainda hoje, os fundamentos sistemáticos da ciência da religião são bastante insatisfatórios" (Wach, 1988, p. 7). Em outros termos, o preço que essa configuração cobra é a ausência de reflexôes teórico-epistemológicas consolidadas que busquem indicar a especificidade da área em relaçâo às demais. Quando elas acontecem, há a tendência de se pensar o estudo da religiáo, mas não especificamente as Ciências da Religiáo. Somente mais recentemente, com a emancipação da área na CAPES, essa temática parece ocupar de maneira mais proeminente uma quantidade mais expressiva de pesquisadores (Huff, Portela, 2012).

Essa situação, em parte, reflete a literatura disponível em português. Ao lado de manuais introdutórios às Ciências da Religião, há poucos autores considerados clássicos na área traduzidos para o português. Não é gratuito, portanto, que Mircea Eliade e Rudolf Otto apareçam com recorrência nas ementas e bibliografias dos cursos. Eles 
acabam sendo mais conhecidos e lidos por sua importância, mas, sobretudo, pelo acesso a suas obras. No entanto, com isso se exclui muitos textos fundamentais. Além disso, no âmbito da inserção internacional, os programas estabelecem mais relaçôes com as áreas que compóem as humanidades do que propriamente com a área de religious studies (ou correspondentes, segundo o país) no exterior. Essa prática tem sua contrapartida. Em vários textos que buscam traçar um histórico da área de Ciências da Religiáo no mundo, a América Latina e o Brasil não são mencionados, mesmo havendo cursos tão antigos. Por exemplo, Gregory Alles, num artigo que busca fazer genealogia da área de maneira mais ampla, evitando certo eurocentrismo, menciona o surgimento e desenvolvimento da área em vários lugares do globo. Há consideraçôes sobre América do Norte, Europa, Centro leste da Europa e Ásia. Em menor escala, África. Mas, a América central, Caribe e América do Sul estão completamente fora do horizonte. A única menção feita é: "Na América do Sul, outras unidades acadêmicas como história, antropologia, sociologia e psicologia, geralmente estudam religiōes locais" (Alles, 2010, p.42) ${ }^{8}$. Por esse e outros exemplos, percebe-se que há desconhecimento internacional do que se produz aqui, inclusive nas universidades públicas. A ênfase exacerbada na interdisciplinaridade traz, como um de suas consequências, a situação de sermos ilustres desconhecidos lá fora.

Diante disso, uma questão que se coloca é: como encontrar um caminho entre a disciplinarização excessiva e a simples sobreposição de várias disciplinas e metodologias? Se o pêndulo tende para o primeiro lado, perde-se o objeto. Afinal, a riqueza da religiáo exige vários ângulos para que possa ser minimamente compreendida. Caso se vá para o outro extremo, o emprego de várias disciplinas e metodologias, sem uma mínima articulação entre elas, pode resultar em sobreposiçóes mal amparadas, gerando dúvidas sobre o rigor das pesquisas feitas. De todo modo, esse desafio parece ser cada vez mais inadiável de ser enfrentado.

Nas universidades públicas, há esforços em concursos recentes para que o perfil dos professores seja aqueles com titulação da área 44 da CAPES, ou seja, em Ciências da Religião ou Teologia. Isso se deve à exigência dos órgãos de avaliação, mas também pelo reconhecimento, ainda que inicial, da necessidade de especialistas mais internos à área? .

No entanto, apesar dessa reflexão mais teórico-metodológica ainda ter muitos passos a serem dados, a organização dos cursos de pós-graduação nas universidades públicas tende a replicar o arranjo mais clássico desse campo de estudos. Essa proposição, já colocada por F. Max Müller e retomada por importantes pensadores das Ciências da Religião, a entende bipartida em dois campos. De um lado, há estudos teóricos e sistemáticos, que se ocupam de aspectos mais estruturantes da religião. De outro, há o estudo empírico e histórico, que busca abordar as religiōes em suas singularidades

8 Algo similar é observado em Jones; Eliade; Adams, 2005, pp. 8761-8767; Antes; Geertz; Warne, 2004. Essa obra busca mostrar como as Ciências da Religião se tornam, a partir da década de 1980, um empreendimento global. Mas, novamente, estão ausentes América Central e do Sul.

9 O caso do mestrado da UEPA é bem peculiar, apesar de também guardar semelhanças. Ele segue a rotina de grande parte dos cursos no Brasil. Ele tem início como graduaçáo. Após certo período de oferta, sente-se a necessidade de fomentar a pesquisa por meio da instalaçáo do mestrado. Cabe observar que muitos professores contratados no momento de implementação deste curso de pós-graduação têm sua formação em Ciências da Religião (Conceição, 2012, p. 307). 
e concretude ${ }^{10}$. A nomenclatura varia segundo o programa, mas é possível perceber essa articulação quando se observa a descrição e o que compreende cada área. UEPA: Linguagens da religião; Religião e sociedades; UFPB: Perspectivas histórico-filosóficas e literárias das religiôes; Ciências sociais das religiōes, educação e saúde; UFS: Religião, conhecimento e linguagens; Ciências empíricas e aplicadas da religião ${ }^{11}$. A única exceção à regra é o curso da UFJF, que se estrutura em três áreas: Filosofia da religião; Religião, cultura e sociedade; e Tradiçóes religiosas e possibilidades de diálogo. No entanto, mesmo nesse caso, é possível encontrar certa referência a uma divisão clássica. As duas primeiras áreas remetem para o aspecto sistemático e empírico, ao passo que o terceiro deriva dos estudos de religião comparada. Enfim, vale observar como ao lado da ênfase na interdisciplinaridade feita por muitos desses cursos, organização adotada é bastante similar às proposições mais clássicas.

\section{Conclusão}

É possível, portanto, perceber que a inserção das Ciências da Religião nas universidades públicas se dá a partir de dois modelos. As primeiras licenciaturas têm início a partir de demandas práticas de formação de professores para o Ensino Religioso, tendo forte acento prático. Dada sua história peculiar, o desafio enfrentando por esse modelo é desenvolver compreensão de Ensino Religioso e de formação de professores que não recaia em modelos confessionais ou proselitistas. No segundo modelo, recorrente em universidades federais, os cursos surgem a partir de iniciativas de professores de outras áreas do saber, mas com interesse na pesquisa sobre religião. O grande desafio é o cuidado com a fragmentação que a demasiada ênfase na interdisciplinaridade pode trazer, ao mesmo tempo em que se busca dar visibilidade da pertinência e do rigor do estudo sobre religião na universidade pública.

Ao propor a inserção das Ciências da Religião nas universidades públicas a partir desses modelos, não pretendo indicar regras fixas. Para além desses contornos comuns, há especificidades que esse tipo de abordagem deixa escapar. Além do mais, apesar dessas diferenças, é interessante observar como os modelos, em alguns aspectos, tendem a se aproximar. Assim, por exemplo, as universidades federais, mesmo as que iniciaram com cursos de pós-graduação, tem mostrado cada vez mais interesse no tema do Ensino

10 Essa divisão aparece em: Müller, 1893, p. 74; Tiele, 1897, p. 08 e p. 302; Kristensen, 1971, pp. 7ss; Kitagawa, 1996, p. 40; Eliade, 1996, p. 123; Wach, 1988, pp. XIXss; Greschat, 2006.

11 No site do programa da UFS, é explicitamente dito que: "Nossa compreensão da área de Ciências da Religião e Teologia, pertencente à grande área das Ciências Humanas, tal como cadastrada na Capes, é de campo de conhecimento que agrega diferentes estudos da religião no âmbito científico e acadêmico, de caráter multi e interdisciplinar, e cuja constituição contemporânea amplia e intersecciona a subdivisão interna tradicional à área desde seu surgimento: por um lado, uma vertente de estudos sistemáticos da religião, em franco diálogo com a tradição filosófica e teológica - mormente ocidental - de estudos da religião, com caráter meta-teórico (epistemológico) e em interface com hermenêuticas culturais relacionadas à arte, literatura, cinema e outras linguagens; e, por outro lado, uma vertente de estudos empíricos e aplicados da religiáo, tomando esta em suas múltiplas configurações a partir de abordagens sociológicas, antropológicas, historiográficas, psicológicas, geográficas em interface com a política, educação, saúde, teoria de gênero/queer, direito etc." (https://www. sigaa.ufs.br/sigaa/public/departamento/portal.jsf?id=857 - visitado em 24 abr, 2019) 
Religioso, tendendo a assumi-la como pertencente a dimensão prática de aplicação das Ciências da Religiáo. Esse aspecto, presente tanto na literatura recente sobre o tema como em documentos oficiais (Junqueira, 2013; Costa, 2019, p.184ss; CAPES, 2019, p.04; Brasil, 2018b, p.13), mostra-se com evidência em disciplinas como "Metodologia do Ensino Religioso" ou instrumentalização, ou nas horas dedicadas à práticas escolares ou estágio, obrigatórias pela legislação vigente. Por outro lado, aqueles que tiveram início com a graduação tendem a buscar maior aproximação com pesquisas mais específicas desse campo de estudos.

O caso da Universidade Federal de Santa Maria (UFSM), único curso em universidades públicas que atualmente é ofertado exclusivamente na modalidade a distância (EAD), é ilustrativo de como se coadunam os dois elementos. De um lado, ele propóe atender à formação de professores para o Ensino Religioso no estado. No entanto, sua articulação se dá por meio da mobilização de professores de outras áreas e atuantes na universidade. Esses aspectos determinam o perfil do curso. Em que pese o fato de estar alocado no Centro de Educaçáo, ele possui forte acento nos aspectos pedagógicos. Isso pode ser constatado pelas disciplinas e pelas ementas. Mesmo disciplinas que aparentemente explorariam aspectos teóricos das Ciências da Religiáo, possuem ementa e bibliografia que aponta na direçáo do ensino religioso e atuaçáo na escola (UFSM, 2016, currículo).

Por isso mesmo, os desafios também tendem a ser bastante próximos. A busca por demonstrar o lugar da pesquisa e do ensino sobre religião na universidade (e na escola) pública, por exemplo, é um desafio que afeta os dois modelos. Isso significa buscar mecanismos teóricos e metodológicos que possibilitem essa maior inserção. Afinal, comparativamente a outras áreas, o número de cursos em universidades públicas é relativamente pequeno. Portanto, há muito ainda a ser feito.

\section{Referências}

\section{Documentos}

BRASIL. Ministério da educação. Base Nacional Comum Curricular para a educação básica, Brasília, 2018a. Disponível em: http://basenacionalcomum.mec.gov.br/wpcontent/uploads/2018/02/bncc-20dez-site.pdf (site visitado em 26/04/2019).

BRASIL. Ministério da Educação. Texto referência para a Audiência Pública sobre as Diretrizes Curriculares Nacionais para o curso de graduação em Ciência(s) da(s) Religiáo(ões). Brasília, 2018.

CAPES. Documento de área. Área 44: Ciências da Religião e Teologia. Brasília, 2019. (disponível em: http://capes.gov.br/images/Documento_ de_\%C3\%A1rea_2019/ciencia_religiao_teologia.pdf)

CFE. Parecer No 190/68, aprovado em 15 de Março de 1968, Processo 733/67 Parecer No 2244/74, Processo 6.930/74.

JAPIASSU, H. Ciência das Religiōes. In: Diário Mercantil, 15/07/1977. 
UERN. Projeto político-pedagógico do curso de Ciências da Religião. Mossoró, UERN, 2001.

UERN. Projeto político-pedagógico do curso de Ciências da Religião. Mossoró, UERN, 2006.

UERN. Projeto político-pedagógico do curso de Ciências da Religião. Mossoró, UERN, 2008.

UERN. Projeto político-pedagógico do curso de Ciências da Religião. Mossoró, UERN, 2014.

UFJF. Aviso 142 de 07/02/1974, a UFJF.

UFSM. Projeto Pedagógico de Curso. Curso de Ciências da Religião - Licenciatura (EAD). Santa Maria: Universidade Federal de Santa Maria, 2016.

\section{Biblioteca}

ALLES, Gregory. The Study of Religions: The Last 50 Years. HINNELS, John. The Routledge Companion to the Study of Religion. London/New York: Routlegde, 2010. 2a edição.

ANTES, Peter; GEERTZ, Arnim G.; WARNE, Randi R. (Ed.). New Approaches to the Study of Religion. Berlin e New York: [s.n.], 2004. v. 1 e 2.

BENEVIDES, Araceli Sobreira; SILVA, Irene de Araújo van den Berg; FILHO, João Bosco; TORRE, Maria Augusta de Sousa. Curso de Ciências da Religião da UERN: possibilidades e desafios. In: RISKE-KOCH, Simone; OLIVEIRA, Lílian Blanck; POZZER, Adecir Pozzer (Organizadores). Formação inicial em Ensino Religioso: experiências em cursos de Ciência(s) da(s) Religião(óes) no Brasil. Florianópolis: Saberes em Diálogo, 2017, pp. 78-99.

BORGES, Ângela Cristina; HORÁCIO, Heiberle Hirsgberg. Curso de Ciências da Religião da Unimontes: experiências formativas no sertão das Gerais. In: RISKE-KOCH, Simone; OLIVEIRA, Lílian Blanck; POZZER, Adecir Pozzer (Organizadores). Formação inicial em Ensino Religioso: experiências em cursos de Ciência(s) da(s) Religião(óes) no Brasil. Florianópolis: Saberes em Diálogo, 2017, pp. 100-115.

CONCEIÇÃO, Douglas da. Perspectivas investigativas da religião na Amazônia: reflexóes sobre a emergência do Programa de Pós-graduação em Ciências da Religião da Universidade do Estado do Pará. In: Numen, vol.15, no 02, 2012, p. 295-318. (disponível em: http://ojs2.uff.emnuvens.com.br/numen/article/view/21853/11897 (site visitado em 26/04/2019).

COSTA, Matheus Oliva. Ciência da religião aplicada como o terceiro ramo da Religionswissenschaft: história, análises e propostas de atuação profissional. São Paulo: PUCSP, 2019. Tese de Doutorado. 
COSTA, Matheus Oliva. Entrevista com Faustino Teixeira sobre sua experiência como egresso da primeira graduação de Ciência da Religião no Brasil. In: Numen, v. 21, no 2, 2018a, pp. 232-291 (disponível em: http://ojs2.uff.emnuvens.com.br/ numen/article/view/22135).

COSTA, Matheus Oliva. Entrevista com Paulo Agostinho Nogueira Baptista sobre sua experiência como egresso da primeira graduação de Ciência da Religião no Brasil. In: Numen, v. 21, no 2, 2018b, pp. 301-305 (disponível em: http://ojs2.uff. emnuvens.com.br/numen/article/view/22131)

COSTA, Matheus Oliva. Entrevista com Wolfgang Gruen sobre sua experiência como egresso da primeira graduação de Ciência da Religião no Brasil. In: Numen, v. 21, no 2, 2018c, pp. 306-316. Disponível em: http://ojs2.uff.emnuvens.com.br/ numen/article/view/22137/14810

ELIADE, M. Observaciones metodológicas sobre el estudio del simbolismo religioso. In: ELIADE, M; KITAGAWA, J. Metodología de la historia de las religiones. Barcelona: Paidos, 1996.

FONAPER. Parâmetros curriculares nacionais: ensino religioso/FONAPER. São Paulo: Ave Maria, 1997.

GRESCHAT, Hans-Jürgen. O que é Ciência da Religião? São Paulo: Paulinas, 2006.

HUFF, Arnaldo; PORTELLA, Rodrigo. Ciência da Religião: uma proposta a caminho para consensos mínimos. In: Numen, v. 15, no 2, pp. 433-456, 2012. (http://numen.uff.emnuvens.com.br/numen/article/viewFile/1659/1454)

JONES, Lindsay; ELIADE, M.; ADAMS, Charles (Ed.). Encyclopedia of Religion, vol. 15. Detroit: Macmillan, 2005. Verbete: Study of Religion: An Overview. pp. 8761-8767.

JUNQUEIRA, Sérgio. O Ensino Religioso a partir do ecumenismo e de valores. In: Numen, v. 17, n. 01, 2014, pp. 89-118.

JUNQUEIRA, Sérgio. Ciência da religião aplicada ao Ensino Religioso. In: PASSOS, J.; USARSKI, F. (Orgs.). Compêndio de Ciência da Religião. São Paulo: Paulinas/Paulus, 2013, pp. 603-614.

KITAGAWA, J. La historia de las religiones en los Estados Unidos de Norteamerica. In: ELIADE, M; KITAGAWA, J. Metodología de la historia de las religiones.

Barcelona: Paidos, 1996.

KRISTENSEN, W. B. The Meaning of Religion. Tradução John B. C. The Haugue: Martinus Nijhoff, 1971.

MIELE, Neide; POSSEBON, Fabrício. Ciências das Religióes: proposta pluralista da UFPB. In: Numen, vol. 15, no 02, 2012, pp. 403-431.

MÜLLER, F. M. Introduction to the Science of Religion. London: Longmans, 1893. 
OLIVEIRA, Lilian Blanck. Formação de docentes para o Ensino Religioso. Perspectivas e impulsos a partir da ética social de Martinho Lutero. 2003. Tese (Doutorado) - Faculdades EST, São Leopoldo, 2003. Disponível em: <http://www3. est.edu.br/biblioteca/btd/Textos/Doutor/Oliveira_lb_td35.pdf>. Acesso em: 08 out. 2016.

PIEPER, Frederico. Aspectos históricos e epistemológicos da Ciência da Religião no Brasil: Um estudo de caso. In: Numen, v. 21, no 2, 2018, pp. 232-291 (disponível em: http://ojs2.uff.emnuvens.com.br/numen/article/view/22159/14804).

RAMALHO, José Rodorval; CALVANI, Carlos Eduardo. Curso de Ciências da Religião da UFS. In: RISKE-KOCH, Simone; OLIVEIRA, Lílian Blanck; POZZER, Adecir Pozzer (Organizadores). Formação Inicial em Ensino Religioso: experiências em cursos de Ciência(s) da(s) Religião(óes) no Brasil. Florianópolis: Saberes em Diálogo, 2017, pp. 100-115.

RIBEIRO, Darcy. O nascimento da UNB. 1995. Disponível em: http://www. fd.unb.br/index.php?option=com_content\&view=article\&id=538:o-nascimentoda-unb-por-darcy-ribeiro\&catid=82\&Itemid=319\&lang=pt (Site visitado em 10/04/2019).

RODRIGUES, Elisa. Questóes epistemológicas do Ensino Religioso: uma proposta a partir da ciência da religião: In: Interaçóes - Cultura e comunidade. Belo Horizonte, V.8, N. 14, pp. 230-241. JUL./DEZ. 2013, p. 240. (disponível em: http://periodicos.pucminas.br/index.php/interacoes/article/ view/P.1983-8478.2013v8n14p230/6245).

SANTOS, Maria de Lourdes Silva; COSTA, Iolanda Rodrigues da; SOUZA, José. Curso de Ciências da Religião da UEPA: uma trajetória de lutas, conquistas e desafios. In: RISKE-KOCH, Simone; OLIVEIRA, Lílian Blanck; POZZER, Adecir Pozzer (Organizadores). Formação inicial em Ensino Religioso: experiências em cursos de Ciência(s) da(s) Religiáo(óes) no Brasil. Florianópolis: Saberes em Diálogo, 2017, pp. 56-77.

SILVA, Victor Leandro da; PALHETA, Francisco Sales Bastos. Curso de Ciências da Religião da UEA. In: RISKE-KOCH, Simone; OLIVEIRA, Lílian Blanck; POZZER, Adecir Pozzer (Organizadores). Formação inicial em Ensino Religioso: experiências em cursos de Ciência(s) da(s) Religião(óes) no Brasil. Florianópolis: Saberes em Diálogo, 2017, pp. 30-55.

SOARES, Afonso Maria Ligorio. Ciência da Religião, Ensino Religioso e Formação Docente. In: Rever, vol.03, 2009, pp. 01-18. (disponível em: https:/www.pucsp.br/ rever/rv3_2009/t_soares.pdf)

TEIXEIRA, F. O processo de gênese da(s) Ciência(s) da religião na UFJF. In: Numen, vol. 15, no 2, 2012, pp. 537-550.

TIELE, C. P. Elements of the Science of Religion. Vol. I, London: William Blackwood and Sons, 1897.

WACH, J. Introduction to the History of Religions. New York: Collier Macmillam, 1988. 
Ciências da Religião nas universidades públicas brasileiras...

Recebido: 11 de maio de 2019.

Aprovado: 29 de agosto de 2019. 